University of Wollongong

Research Online

Faculty of Arts, Social Sciences and Humanities

- Papers

Faculty of Arts, Social Sciences \& Humanities

$1-1-2020$

Capitalism in Australia: New histories for a reimagined future

Ben Huf

Yves Rees

Michael Beggs

Nicholas Brown

Frances Flanagan

See next page for additional authors

Follow this and additional works at: https://ro.uow.edu.au/asshpapers

Research Online is the open access institutional repository for the University of Wollongong. For further information contact the UOW Library: research-pubs@uow.edu.au 


\title{
Capitalism in Australia: New histories for a reimagined future
}

\begin{abstract}
The Author(s) 2020. Capitalism is back. Three decades ago, when all alternatives to liberal democracy and free markets appeared discredited, talk of capitalism seemed passé. Now, after a decade of political and economic turmoil, capitalism and its temporal critique of progress and decline again seems an indispensable category to understanding a world in flux. Among the social sciences, historians have led both the embrace and critique of this 're-emergent' concept. This roundtable discussion between leading and emerging Australian scholars working across histories of economy, work, policy, geography and political economy, extends this agenda. Representing the outcome of a workshop convened at La Trobe University in November 2018 and responding to questions posed by conveners Huf and Rees, five participants debate the nature, utility and future of the new constellation of 'economic' historical scholarship. While conducted well before the outbreak of COVID-19, the ensuring discussion nevertheless speaks saliently to the crises of our times.
\end{abstract}

\section{Publication Details}

Huf, B., Rees, Y., Beggs, M., Brown, N., Flanagan, F., Palmer, S. \& Ville, S. (2020). Capitalism in Australia: New histories for a reimagined future. Thesis Eleven,

\section{Authors}

Ben Huf, Yves Rees, Michael Beggs, Nicholas Brown, Frances Flanagan, Shannyn Palmer, and Simon Ville 


\title{
Capitalism in Australia: New Histories for a Reimagined Future
}

\author{
Ben Huf (University of Sydney) and Yves Rees (La Trobe University), \\ with Michael Beggs (University of Sydney), Nicholas Brown (ANU), \\ Frances Flanagan (University of Sydney), Shannyn Palmer (ANU) \\ and Simon Ville (University of Wollongong)
}

Capitalism is back. Three decades ago, when all alternatives to liberal democracy and free markets appeared discredited, talk of capitalism seemed passé. No longer was the West simply moving into a post-industrial society, as Daniel Bell (1974) predicted, but all the world was entering a timeless, globalised market economy. The 'end of history' was nigh. Now, after a decade of political and economic turmoil, capitalism and its temporal critique of progress and decline again seems indispensable to understanding a world in flux. According to pundits worldwide, the Great Recession, Occupy movement, eurozone crisis, increasing automation, growing inequality, the revival of political populism and the climate emergency are all symptomatic of a broader 'crisis' in capitalism. Manifestoes such as Paul Mason's Postcapitalism (2015) and Thomas Piketty's Capital in the Twenty-first Century (2013) top bestseller lists, eminent scholars debate the future and end of capitalism (Wallerstein et al 2013), while talk of a Universal Basic Income and a Green New Deal have entered the mainstream. Even the Economist has entered the fray, with a November 2018 cover diagnosing a mass loss of faith in capitalism, especially among youth.

What should we, as scholars and citizens, make of capitalism's return? To be sure, some will insist that - for those who looked - capitalism never went away. But it is also true that for the past generation, critical scholarship has, for a variety of political and theoretical reasons, had an uneasy relationship with capitalism. As demonstrated in the pages of this journal, scholarly debate over the past thirty years has ranged from qualifying a 'postindustrial-', 'knowledge-' or 'bio-information capitalism' (Liagouras 2005; Murphy 2005; Peters 2012), to theorising new frameworks that capture the multiplicities of 'modernity' (Wagner 2001, 2010; Arnason 2001; Bauman 2002) or 'neoliberalism' (Flew 2014), and post-structuralist attacks on Euro-centric grand narratives, doing away with capitalism altogether (Delanty 2010). For Australians, it has meant theorising an Antipodean ‘modernity' or a revived ‘settler capitalism' (Beilharz 2005; Beilharz and Cox 2007). The 
return of a more obdurate capitalism as the touchstone for debating our times thus presents challenges at once intellectual and political. For some, it risks returning to a term so capacious and ill-defined that it risks becoming devoid of meaning altogether (Levy, 2017; O’Sullivan, 2018). Others fear that (re)centring 'capitalism' simply reinscribes its hegemonic status and elides already-existing alternatives (Gibson-Graham 2014).

Among the social sciences, historians have led both the embrace and critique of this 're-emergent' concept (Kocka 2016). Nowhere is this more apparent than in the United States, where a much-hyped sub-field, 'the new histories of capitalism' (NHOC), is advertising itself as a corrective to the long neglect of economic enquiry in the wake of the 'cultural turn'. 'After decades of "history from below" focusing on women, minorities and other marginalized people seizing their destiny,' the New York Times explained, 'a new generation of scholars is increasingly turning to what, strangely, risked becoming the most marginalized group of all: the bosses, bankers and brokers who run the economy' (Schuessler, 2013). This field has focused on 're-embedding' economic life in structures of law, social norms, knowledge and power (Kramer 2016), although it is equally characterised by Ivy League graduate programs, publications and conferences. No sooner had the NHOC emerged, than critiques followed regarding the field's novelty, masculinist politics and lack of definitional precision or consensus (Enstad, 2019; Hilt, 2017; Hartigan-O'Connor, 2016). Elsewhere, scholars probe similar terrain, some under the umbrella of a 'material turn' or 'new labour history', while others intersect economic crisis with ecological fallout in terms of a Capitolocene (Sewell 2010, 2014; Plumpe, Lenger and Kocka 2017; Smith 2018; Palmer 2017; Moore 2017). Analogous conversations are underway in Australia. Since 2017, local scholars have re-interrogated capitalism as a historiographical problem (Huf and Sluga 2019), urged cultural historians to 'seek a new materialism' (Forsyth and Loy-Wilson 2017) and reclaimed economic history as a rich domain of interdisciplinary inquiry (Ville and Wright 2017).

The following roundtable dialogue extends this research agenda. It represents the intellectual harvest of a workshop on 'Capitalism in Australia: New Histories for a Reimagined Future' that we convened at La Trobe University in November 2018. As local historians began to re-centre the economic in their individual research, we felt it timely to gather scholars from other disciplines and consider history's role in what has become a larger intellectual and political moment of economic soul-searching. Over two days, the workshop congregated historians, economists, political economists, anthropologists, political scientists, 
sociologists, geographers and policy experts for conversation across disciplinary, political and generational divides. ${ }^{1}$

Responding to questions posed by Huf and Rees, five participants have reprised the workshop's wide-ranging discussions over the nature, utility and future of the new constellation of 'economic' historical scholarship. They include three historians (two female ECRs - Shannyn Palmer, ANU, and Frances Flanagan, Sydney — and one male professor, Nicholas Brown, ANU), an economic historian (male professor, Simon Ville, Wollongong) and a political economist (male senior lecturer, Mike Beggs, Sydney). Huf and Rees are early career historians respectively based at Sydney and La Trobe. The resultant conversation constitutes an Australian answer to the Journal of American History's 2014 interchange on 'The History of Capitalism', and takes the temperature of current thinking about capitalism, economics and history in the Australian context.

In the best interdisciplinary spirit, we present this forum to readers of Thesis Eleven a journal that has long promoted intersecting social theory, historiography and critical inquiry - to advance these discussions. Although, as US historian Paul Kramer (2017) writes, doing history in 'dark times' can 'feel suspiciously like retreat', our current moment of perceived crisis makes critical engagement with the past more imperative than ever, as history 'infuses how we think about everything else.' With only eleven years remaining to avert catastrophic climate change (IPCC, 2018) in a context of widening inequality, we urgently need histories engaged in interdisciplinary dialogue to map how we got to this point.

Over the last few years, in history departments across the world, we've seen a renewed interest in the economic and material dimensions of the past. From your respective scholarly vantage points, how do you account for this, and in what ways do think such developments are similarly being approached in Australia? How does this differ from, or relate to, fields such as labour history, business history and economic history, which are traditional strengths of Australian historiography?

\footnotetext{
${ }^{1}$ We wish to again thank those who participated in the workshop: Jon Altman (Deakin); Aditya Balasubramanian (ANU); Mike Beggs (Sydney); Judith Bessant (RMIT); Nicholas Brown (ANU); Frank Bongiorno (ANU); France Flanagan (Sydney) Ross Garnaut (Melbourne); Katherine Gibson (Western Sydney); Ben Huf (Sydney); Karen Hussey (UQ); Dianne Kirkby (La Trobe); Shelley Marshall (RMIT); Shannyn Palmer (ANU); Tamson Pietsch (UTS); Yves Rees (La Trobe); Glenda Sluga (Sydney); Jim Stanford (Australia Institute); Chip Van Dyk (Melbourne); Simon Ville (Wollongong); Emmanuelle Walkowiak (La Trobe); Andrew Walter (Melbourne); Claire Wright (Macquarie).
} 
Simon Ville: Many disciplines are engaging, or re-engaging, with the economic past. In the recent World Economic History Congress (Boston, August 2018), a major triennial meeting, participants came from a broad range of scholarly backgrounds besides economic history economics, history, business, area studies, and social sciences, in particular. About 30 per cent of the 1000 or so attendees worked in history departments, trailing slightly the number of economists. ${ }^{2}$

The methodologically diverse, interdisciplinary nature of economic history has always attracted the open-minded and refugee-like 'escapees' of other disciplines. However, it appears that there has been a broader revival of interest in economic history in recent years, particularly by its 'parents', history and economics. There is an emerging literature on this phenomenon including Kenneth Lipartito's (2016) contribution to the American Historical Review in which he concluded that a cross-disciplinary convergence into economic history was occurring.

Growing inequality in the late twentieth century, the marginalisation of particular social and ethnic groups, and the systemic failings revealed by the Global Financial Crisis/Great Recession of 2007/8 all revived discussion and activism about the validity and future of capitalism as the dominant economic system. Student attitudes piqued, while historians, especially younger ones, have been alert to the need for an informed and empowering voice in an era of major economic change and dislocation.

Led by its resources industries, Australia has experienced fewer economic tremors in a period of sustained domestic economic growth over a quarter of a century. The economic historical questions are more about understanding the basis and durability of such success and why massive improvements in living standards have not been equitably shared, with minimal evidence of the closing of the gap with indigenous Australians.

What sort of economic history might we expect from the revived interest of historians in Australia? The history of capitalism, flourishing in the USA, offers some hints. It is likely to be less quantitatively technical and, perhaps, theoretical but more critical and pedagogically broader than the variety commonly practised by economic historians with a background in economics. It will be interesting to see the extent of engagement of historians with business history. The work of business historians in Australia and elsewhere in many respects sits close to that of historians, favouring the use of archives, emphasising the diversity of experiences, drawing on cross-disciplinary work, and giving greater voice to

\footnotetext{
${ }^{2}$ Data from a current project with Dr Claire Wright.
} 
agents. Labour history, using similar methods, has traditionally been more critical of enterprise than business historians, although, facing extinction, many in the field have reinvented themselves as historians of 'good' businesses such as cooperatives and socially aware enterprises.

Recent papers by American economic historians such as Margo (2018) and Hilt (2017) have been highly critical of the history of capitalism. In Australia, one of the challenges is to develop appropriate agendas that bring together the skills and knowledge of historians and economists in constructive and engaging conversations.

Shannyn Palmer: As well as growing inequality and greater economic hardship for an everincreasing number of people globally, I think that the current climate crisis has led to a collapse of faith in our economic systems. As large parts of the Australian continent are ravaged by drought, catastrophic floods and bushfires, in the wake of a summer that has seen every state break highest recorded temperatures with alarming frequency, and as the crisis in the Murray-Darling Basin deepens, it has become increasingly apparent that our economic systems are not only unjust and inequitable - they are also unsustainable. In Australia, historians have a lot to offer in relation to a greater understanding of settler capitalist extractivism - pastoral, mineral, agricultural - and how this particular discourse and practice of political economy has led us to the circumstances we currently face.

I think many historians, like scholars from a wide range of other disciplines, are turning to the material and economic dimensions of both the past and present in order to critically intervene in the economic, social and environmental crises we currently face. In the Australian context, this political, or activist, impulse is reflected in Hannah Forsyth's and Sophie Loy-Wilson's (2017: 188) recent call for 'a new materialism' in Australian history, which argues for a combination of cultural and structural approaches to the past in order to properly historicise capitalism and therefore seek 'justice within it, in the present'. Another example is Frances Flanagan's (2019) recent lecture and essay on 'Climate Change and the New Work Order', which argues that Australia's past can be a source of inspiration for how we might respond to the present environmental crisis and show us the way toward a new social contract that recognises that "the purpose of our economy...is to facilitate the flourishing of our living systems'.

Following Lipartito's $(2016 ; 137)$ 'Reassembling the Economic', I think these examples demonstrate his observation that this 'new materialism' does not call upon economics to explain the past. Rather, the past is used to show how the economy came to 
assume its form in specific times and places, highlighting that present-day inequalities are neither necessary, or inevitable. Furthermore, it insists that it is within our power to reimagine and restructure the world in a more just and equitable way and suggests that historians have an important role to play in this undertaking.

Frances Flanagan: I agree with Simon and Shannyn that the materialist turn in Australian history is occurring against a distinctive political backdrop. While we share elements of the US and UK economic trajectory (such as rising levels of household debt, a globally interconnectedness, diminishing worker collectivism), GDP has continued to rise for the last 27 years. Environmental crises afflicting the Great Barrier Reef and Murray-Darling basin, together with civil society campaigns on economic inequality have started to trouble the 'enchantment of politics by economics' in high political discourse. But for the most part it remains the case that liberal economics remains the lingua franca of power in Australia. As relative 'spectators' in the current turbulence of global capitalism, Australian historians are called upon, as Simon observes, to reflect upon the sources of Australia's relative prosperity. But there is also an important role they must play in reflecting on the fragility and finiteness of those sources, in light of what we can observe internationally and recent scientific publications such as the report of the IPCC, that indicate the environmentally catastrophic consequences of following a 'business as usual' economic pathway in the next decade.

There are a few other contextual dynamics that are shaping Australia's historical turn to materialism worth mentioning. The first is the fact that Australia has largely completed the process of dismantling the formal apparatus of legal discrimination that subjugated women, non-whites and non-heterosexual people, but that these groups continue to experience inequality and discrimination. The persistence of such inequality in the face of formal legal equality imposes new explanatory pressure on historians to grapple with, and foreground, the entanglements of gender, race and sexuality with questions of class, consumption, work and capital in their accounts of the past. Hannah Forsyth's (2019) research on women and the professions in the Australian Economic History Review provides one example of such an approach.

The speed and apparent acceleration of the 'commodifying frontier' of capitalism, enabled by the widespread introduction of artificial intelligence and big data technology, also bears upon history-writing. The rise of the 'gig economy' has drawn everyday attention to the process of commodification of labour, and given new salience to issues that have long 
preoccupied labour historians, such as worker resistance, agency and collectivism in the face of the detailed division of labour and technological change. Studies of labour and financial institutions that pre-date $20^{\text {th }}$ century industrial formations take on new relevance in this context, such as Michael Quinlan's (2017) work on colonial worker collectivism and Nikola Belnave and Greg Patmore's (2017) work on co-operatives and mutuals.

As Australian historians, we necessarily participate in a global historical conversation that is underpinned by transnational systems: individual academic careers are made and measured by contributions to international journals, conferences and networks, which means that any significant historiographical 'turn' on the part of historians working in the US and UK will always, to some extent, be shared in Australia too. Material contexts are also important in grasping, too, why it is that much important scholarship on Australia's capitalist past is taking place outside history departments and journals, in favour of comparatively better-resourced business schools. Consider, for example, the career of Christopher Wright (1995), author of a 1995 monograph on the history of Australian employers who is now publishing on the entanglements of culture, corporate activity and environmentalism in Australia (Wright, 2015) - issues that might be viewed as core 'new histories of capitalism' themes - but doing so in management journals, and within a social science framework.

Michael Beggs: I am coming from a different angle to the historians, as a social scientist drawn towards history. But my discipline, political economy, self-consciously takes its name from a time before the separation of the disciplines. In classical political economy, as Hobsbawm (1997: 98) put it, 'history and economics grew up together'; its originators 'refused to isolate economics from the rest of the historical transformation of society in which they saw themselves engaged.'

History was central for the Australian political economy movement of the 1970s. Historical essays made up much of the five volumes of Essays in the Political Economy of Australian Capitalism (Wheelwright and Buckley, 1975), assembled to showcase the movement. Wheelwright (1975, Vol. 1: 1) wrote in the first volume's introduction that the collection "originated in the belief that a "History of the Political Economy of Australian Capitalism from the Earliest Times to the Present Day" should be written.' And of course this was the decade of radical histories of Australian capitalism, from McQueen's A New Britannia (1970) to Connell and Irving's Class Structure in Australian History (1980).

So in many ways the arrival of the new 'history of capitalism' seems like a return to a conversation that dropped off fairly abruptly at some point in the 1980s. It is interesting that 
it has been historians seeking out the other disciplines this time. 'Capitalism' is a social science word - or, really, a word from before the fragmentation of our disciplines. I get the impression many historians have long been suspicious of that kind of word-a grand abstraction. Historians seem more comfortable with nuance and concreteness. Of course the new historians of capitalism are not talking 'modes of production' or 'complex and differentially articulated structures in dominance' or anything like that (thankfully). But there is again a sense of something underlying all the vignettes, that it makes sense to link them together with a word referring - however vaguely - to a great social transformation that is - however complex - a process with some kind of unity.

Ironically, the social sciences have also become skeptical of such grand abstractions: 'capitalism' has gone out of fashion. But it has been replaced by a succession of vaguer abstractions like 'neoliberalism,' 'globalisation,' 'financialisation'-all suggestive of epochal shifts or historical processes, but without a lot of historical analysis behind them. The 'history of capitalism' is, among other things, an opportunity for social scientists to exercise their historical muscles again.

Simon mentioned skepticism from many economic historians about the 'history of capitalism'. I have some sympathy: a history of capitalism without economics - theory and statistical analysis - would be impoverished. I don't agree with the sometimes unstated assumption that economics is an inherently conservative discipline and cultural studies inherently critical. Some political economists of the 1970s made the mistake of dismissing 'orthodox' economic history and cut themselves off from a rich tradition. But economic history can't be left to the economists, either, because it has become too narrow in the questions it asks and the tools it considers acceptable in answering them.

Nick Brown: As Lipartito (2016) outlines in the article mentioned by Simon, the trend in recent scholarship is that processes of 'financialisation' and especially commodification (drawing on political and cultural perspectives) have replaced emphases on production (with its social and labour history dimensions) as the way in which a new generation of historians (and a wider readership: look in your bookshops) are finding their way to and through economic perspectives. 'The maw of capitalism', Lipartito (2016: 114) notes, ranges into 'hybrid forms' with this approach, as the markets which create commodity values are tracked in careful, engaging detail. Scholarship draws on an increasingly diverse archive in seeking (as Shannyn puts it) not to 'call upon economics to explain the past' but to 'show how the economy came to assume its form in specific times and places'. 
One of the key challenges ahead is determining how we navigate between the heightened salience of commodification, as Nigel Thrift (2006: 282) has argued, its current meshing of commodity and consumer in relentless cycles of experimentation, that expanding 'maw' of capitalism (assuming, with whatever reservations, we still need to work with such a concept), and the widespread desire (highlighted by Forsyth and Loy-Wilson [2017: 181] ) to restore a sense of 'agency' to historical narratives.

The discussion so far has stressed the extent to which economic and materialist perspectives might, as Simon puts it, 'give greater voice to agents', inform 'an alert and empowering voice in an era of major economic change', and even - Shannyn writes - an 'activism' in scholarship. The coupling of agency and commodification, however, begs its own questions of power and objectification/subjectification. And a materialist approach inevitably means that agency must be a relative term/practice. How are we to account for, or evaluate, such agency as the point of purchase from which to address the implications of our histories for those patterns of prosperity and inequality, or the origins of climate crisis, we have identified as priorities for historical attention? How are we to understand the beast behind the maw?

The issues here are not peculiar to Australia but there are distinct Australian traditions in dealing with such questions. One perception of the beast was clear, as Michael reminds us, in Wheelwright and Buckley's Essays in Political Economy series, outlining a defiant Marxist project. The initial volume (eds Wheelwright and Buckley, 1975: vi) began with the preface to The Critique of Political Economy: 'the mode of production in material life determines the general character of the social, political and spiritual processes of life'. The last in 1983, opened with the observation that in addressing The Communist Manifesto to the "contemporary world ... the word "bourgeoisie" could be changed to "transnational corporation", as Australia seemed then to be sliding down 'the pecking order' of the global division of labour (Wheelwright, 1983: 2-3).

As Simon observes, that slide has not turned out to be the story for Australia - or not for all sections of Australia - since then (the market-oriented reforms of the Hawke-Keating governments saw, in part, to that). A different kind of project has been required to address, as Frances puts it, "the speed and apparent acceleration of the "commodifying frontier"'. In this context, Andrew Wells' Constructing Capitalism (1989) provided, so Henry Paternoster (2017) argues, the last successful exercise in bridging between a 'rigid adherence' to 'economics' and 'culture' in Australian historical writing. Peter Beilharz and Lloyd Cox (2007: 112) have similarly noted the waning of the 'settler capitalism' model since the 1980s, 
with its emphasis on 'the early commodification of land and hence labour' in the Australian colonies. It is striking, however, that such approaches have figured little in recent Australian colonial historiography, which has centred on the gendered, imperial, racial identities through which (for example) land was claimed and relationships legitimated, and in which 'capital' functioned essentially as the adaptive 'human' performance of labour and value. As Simon and Claire Wright (2017: 155) have argued, a 'new form of micro-economics' has come with this interest, attentive to the influence of institutions, innovation, education and much else. But how do we translate agency in those contexts to the wider patterns of change - in history, and in the use of history - to which we aspire?

Beilharz and Cox's (2007: 122) point in regretting the fading of the 'settler capitalism' approach is in part that with it has gone the 'alternative modernities' in which dynamics might be imagined for an 'old Australia' not simply awaiting the discipline of globalised markets. Although attention to diverse economic archives and actors leads to welcome inclusivity, it is important that these stories retain capacity to test both the microand the macro- models of the 'economy' in which they have their agency. One of the pleasures of working with Ian McLean's (2016) Why Australia Prospered as an undergraduate text has been his insistence both on a comparative perspective (what accounts for the distinct pathways of Australian development, in relation to other settler economies?) and on historicizing the choices and the learning that have shaped that development. I take Michael's caution regarding 'grand abstractions', but the next step in finding an 'alert and empowering voice' might require achieving the critical distance to fully historicise such choices.

A number of you have noted the re-emergence of grand abstractions such as 'capitalism', 'neoliberalism', 'financialisation' and 'globalisation' as organising frameworks of much research today (but also, ironically, the relative disappearance of 'settler capitalism' in Australian historiography). Many scholars, not just historians, have until recently advocated the abandonment or active dismantling of such constructions. What are the risks and the benefits of a return to such analytics? Is there an implicit presentism (or even 'activism', to quote Shannyn) in adopting these categories and what does this mean for our histories? 'Presentism' is often viewed pejoratively, as a threat to scholarly rigour, but to what extent is this a valid concern in relation to recent and emerging scholarship on the material and economic past? 
Michael Beggs: We shouldn't overstate the naivety of the older use of 'grand abstractions' like 'capitalism'. 'Capitalism' was never an uncontroversial term. It always had to be hedged and apologised for, and that drove people to think carefully.

Ninety years ago Tawney (1930: 7) already referred to it as 'an ambiguous, if indispensable word'. Seventy years ago, Dobb (1947: 1) opened his book on the 'development of capitalism' with a rebuttal to historians who rejected the term in light of 'the variety and complexity of historical events'. Complexity is obvious; abstraction helps us make sense of it. Fifty years ago, Braudel (1977: 45-46) wrote: 'Irritated, one shoos [capitalism] out the door, and almost immediately it climbs in through the window. There is no adequate substitute for this word, and that fact alone is symptomatic.'

Any attempt to explain things related to provisioning, work and exchange in the last few centuries will not be able to trace causal chains very far before running into a network of linked concepts: wages, prices, interest, profit, money, credit, etc. These are social facts: you may not be able to point to 'capitalism' out there in the world, but you can point to instances of these other things. It is difficult to deny that they are systematically related to one another, and that they connect people in a social web that stretches around the world. The web is really there, and it and its component threads have histories, but they are too complex to grasp without abstraction.

You don't necessarily need a grand abstraction like 'capitalism' to think about these things. Economics does without it. But it thrived at the intersection of history and social science because it helps to explore the mutual dependence not only among these economic relations but also between them and other social relations. 'Capitalism' highlights the historical specificity of the economic categories, and their dependence on extra-economic conditions. We don't have to choose between a 'grand abstraction' like 'capitalism' and smaller-scale models, or interpretation and detailed description; it gives us a map on which to connect pieces together.

'Neoliberalism' and all the '-isations'-_modernisation,' 'globalisation,' 'financialisation,' etc., filled the space 'capitalism' used to occupy. They seem less useful abstractions. They imply processes and change, and so are historical in a sense. But the nature of the processes is obscure. There are so many definitions of 'financialisation,' referring to all kinds of more specific things: a proliferation of exotic financial instruments, an increasing proportion of profits accruing to the financial sector, increased household indebtedness, behaviour increasingly oriented towards financial calculation. These may all be trends, but are they all facets of some unified process? This seems to be taken for granted. 
Shannyn Palmer: As Lipartito (2016: 126-127) points out, 'capitalists have a lot to answer for' and in this sense, the new histories of capitalism have a moral perspective. I think that it is this moral perspective that underlies the presentism of much of the new histories of capitalism. In their call for a 'new materialism' in Australian history, Forsyth and LoyWilson (2017: 183) write that they seek to 'consider the structural and cultural dynamics of inequality in the present'. Their call for a new materialism is openly declared has having a political imperative: '[If we] hope for a history that seeks a better world we need to historicise, rather than reinforce, these changing economic systems' (Forsyth and LoyWilson, 2017: 183).

Therein lies the rub between the presentist/activist impulse in much of the "new histories of capitalism' and the grand abstraction of capitalism itself. As Michael points out, we need abstraction to make sense of the complexity if we want scholarship to do more than just narrate one event after another. But I can't help but wonder, by historicising capitalism defined by Forsyth and Loy-Wilson (2017: 188) as 'seeking to understand capitalism as a historical subject [in order to] seek justice within it, in the present' - do we run the risk of reinforcing capitalism as the dominant economic system?

As Lipartito (2016: 127) points out, for all its strengths, the new history of capitalism is not well equipped to deal with earlier periods before capitalism or the histories of noncapitalist or mixed economies. And yet, marginal, or non-capitalist forms of enterprise are more prevalent, and account for more hours worked and more value produced than the capitalist sector (Gibson-Graham, 2008: 615). As feminist economic geographers J.K Gibson-Graham have argued, representations of capitalism as an obdurate structure or system has the performative effect of obscuring so-called non-capitalist forms and processes, since power is assumed to concentrate in capitalism and be largely absent in other forms of economy: 'thus capitalism [is] strengthened, its dominance performed, as an effect of its representations' (Gibson-Graham, 2008: 615). In highlighting the performative nature of scholarly knowledge, Gibson-Graham (2008: 615) argues that if we seek justice and structural change in the present, then scholars need to be aware of their role and responsibility in creating or performing the worlds we inhabit and their power to 'bring new worlds into being'.

I think that the presentist impulses, or moral perspectives, implicit in much of the new histories of capitalism requires a deeper engagement with the performative implications and political limitations of mobilising grand abstractions like capitalism as an analytical framework. Perhaps, as Michael suggests, the answer is to use these abstractions self- 
consciously and in conjunction with other frames of analysis. Or perhaps, as Gibson-Graeme (Gibson-Graham, 2008: 615) argue, it is a matter of dislocating the hegemonic framing of capitalism, so that its 'dominance in any time or place [becomes] an open question rather than an initial presumption'.

Frances Flanagan: There are many ways of writing bad history. As academic historians, we are trained to recognise and denounce any narrative with the faintest whiff of historical determinism, teleology or anachronism; from our undergraduate years we are taught to decry the role of historical cheerleader or undertaker who celebrates or grieves for a particular 'side' in a historical conflict within a received grand historical drama. Renewed academic attention to the history of capitalism seems unlikely to suddenly render these academic solecisms acceptable. It is possible to write flawed history about any historical abstraction, whether it be capitalism, racism, sexism or nationalism; even non-'ism' periodisations that purport highlight radical discontinuities between past and present can nevertheless carry with them 'presentist' politics (as Peter Beilharz and Lloy Cox [2007] argued was the case for the 'Australian Settlement' thesis that displaced earlier constructions of 'settler capitalism'). To abstain from the task of historicising capitalism and its variants simply because others have written about these constructions in ways that are conceptually woolly or teleological or deterministic seems a terribly wasted opportunity.

As habitual contextualisers, historians are likely to have particular insights into capitalist formations that are of acute relevance contemporary readers, and are unlikely to arrive from other disciplines. The impulse to look outside the received frame of any given concept and inquire into its material and cultural foundations, its temporal and geographic contingencies and its interdependencies is a core task of the historian. I agree with GibsonGraham's (2006) suggestion that the hegemonic status of capitalism should be an open question rather than an initial presumption, but would go further and say such a stance is a hallmark of all good history. It is also an approach likely to produce work that is simultaneously rigorous and relevant, since it is hard to imagine a purer strain of antihistorical thinking than the Thatcherite precept (that still looms behind a great deal of current policy making) that 'there is no alternative' to a market society.

Some of the most impressive recent histories of capitalism that illuminate a great deal about present-day politics are products of the application of straightforward historical 'tools of the trade.' Adam Tooze's (2018) book Crashed, for instance, uses descriptive historical narrative to explode the myths about the differential economic footing of Europe compared to 
the US, as well as revealing the extent the massive mobilisation of state action that attended the eurozone crisis, and the actions of the individuals in the European Central Bank and US House of Representatives in fomenting it. Similarly, historians such as Erin Hatton (2011) and Louis Hyman (2018) have cast powerful light upon the origins of the widespread 'temporariness' of contemporary work formations in America today. In both cases, their arguments - that corporate actors engaged and mobilised with categories of race and gender in the 1950s and 60s to forge a new 'common sense' notion of workers as economic 'liabilities' - are best understood as well-executed examples of traditional empirical narrative historical methods. Their combination of sources might be said to be slightly unusual, in that both bring together the economic and the cultural (analysing popular magazines and newspapers, for example), they are hardly wildly unconventional.

The imperatives of scholarly rigour and relevance to present-day concerns seem then, in my view, to be not particularly at odds. I worry more about the limitations of our methodological 'toolbox', which was overwhelmingly crafted in the analogue years of the $20^{\text {th }}$ century, in being able to cope with the vast and disaggregated empirical source base created by late $20^{\text {th }}$ and $21^{\text {st }}$ century forms of global capitalism. If we are to keep producing work that is rigorous and relevant, we will need to be able to access and interpret information about far flung supply chains housed within currently opaque and widely dispersed digital systems, algorithms and millions of fragments of human communication contained in text messages, emails and myriad platforms. The historians' questions of capitalism are, I think, good and important ones for our times, but we won't be able to ask them if we do not have the ability to make the necessary sources legible.

Nick Brown: I suspect I sometimes puzzle graduate students, regardless of their topic, by suggesting they read the final chapter of Ian Watson's (1990) Fighting over the Forests. Maybe its nostalgia on my part, but when I read that book, also as a graduate student, not long after it was published, I found it helped. There was, then, no direct connection to my topic, although Ian's interest in understanding the experiential and identity-based engagement of both timber workers and conservationists in forest management issues helped test aspects of my own project on Cold War politics. His insistence was that for all the ostensibly classbased origins of the conflict between these groups, a more fundamental - and shared conflict existed for both in the conditions under which they were required to 'sell their labour' (Watson, 1990). The challenges facing the manual skills of one group (staring down advanced mechanisation) were different to the embattled intellectual skills of the other 
(navigating the corporatisation of expertise through the 1980s). Each however, was 'fighting' not just for the recognition of an inherent 'cultural capital', and certainly not for a disembodied ideology, but for a place in the shifting dynamics of a crisis-prone/crisisgenerating capitalism (Watson, 1990). Ian's point was that to understand the conflicts between them, and in an unfolding 'cultural production' of ecological and economic value, required taking seriously the conditions that determined their relative agency.

I refer students to this book not because I agree with every aspect of its approach, but because I think it remains an effective example of how theoretical abstraction (which Ian keeps to discrete passages) can be engaged with the immediacy and accessibility of a pressing issue and a robust, demanding, compassionate archive (drawn, for Ian, primarily from extended interviews). And, to put it simplistically, I still appreciate his insistence that what you do to one half of the equation you need to do to the other.

In this exchange, we have shared a commitment to historicising capitalism, and to seeking a balance between the abstractions that must inform conceptualising the processes under analysis and their lived (and increasing) inequalities. Watson's (1990) engagement with the testimonies of labour might be related to Shannyn's sense of the 'performative' emphasis in Gibson-Graham's work (2006), although I suspect Watson (who has more recently worked on the close fit between the wage-related inequality and the deindustrialisation and financialisation of the Australian economy [Watson, 2015; 2016]) would question the capacity to step outside capitalism not as a totalised structure but as pervasive economic, social and cultural processes. To some extent, this takes me back to my initial point about the relativities of agency. Our historicising should seek to be comprehensive, including of concepts such as equality.

As Frances notes, works such as Adam Tooze's (2018) celebrated Crashed provide a powerful historical account of recent crisis, but such detailed dissections of the 'financialisation' of capital perhaps still struggle to break out of the kind of self-referential vortices of finance itself ('operations' which, Adam Tooze [2018] notes - but only on page 614 of a 616 page book - can have the effect of 'void[ing] the presence of politics'). Impressive though Tooze's account might be, I take Aditya Chakrabortty's (2018) point in noting that while a 'brilliant book', Crashed is 'ultimately bloodless' is failing to rise above the dealing to understand both the systems in which it occurred, and its real impacts. Some greater distancing, and empathy is required to achieve that purchase, and both require abstraction (to understand the processes, and to fully comprehend its agents and objects). 
Watson's (1990) attention to the forestry debates on the 1980s is now, perhaps, too much of the past to be effective for my supervisorial ministry. I am thinking, at last, of updating my recommendation to a 2006 Economy and Society article by Nigel Thrift I noted earlier. Thrift argues that a sense of history is crucial to understanding the most recent iterations of processes in which the commodity and the consumer are being caught in a new, relentless cycle of experimentation and reproduction. The domains of knowledge, space and time, Thrift (2006:281-82) argues, are captured by 'a kind of generalised outsourcing', in which the labour of people is displaced into endless 'innovation', dissolving the old dialectic of producer-consumer into an unprecedented, amorphous 'full palette capitalism'. The looming anarchy Thrift detects in such a trajectory might be a fragile base for the kind of critique we are seeking, and certainly is haunted by 'presentism'. And the article is not an easy read. But the trajectory he traces seems to me, as Watson did in 1990, a powerful way of historicising trends not only in our subjects, but our engagement with them.

Simon Ville: Grand abstractions are often compelling at first blush but more disappointing if one takes a closer look 'under the hood' to make more specific sense of them. Contributors to the roundtable have mentioned other relevant abstractions and I might add industrialisation, imperialism, and the great divergence, but capitalism is the grandest of the grand for economic history. Reading the stimulating contributions to this roundtable reminds me that we still cannot pin down this elusive concept. Was there a pre-capitalist age, can mixed economies also be classified as capitalist? I would answer no and yes respectively. Profitseeking enterprise, with its many positive and negative effects, has a very long history, while few economies, ancient or modern, lack some form of government intervention in markets. When we workshopped the Cambridge Economic History of Australia at ANU in 2012 the older members of the group commented that previous generations considered fixed capital the locus of such overarching works, but now we were talking more about the role of knowledge and other intangible assets (eds Ville and Withers, 2015). The so-called knowledge economy is, perhaps, another manifestation of capitalism.

Gibson-Graham (2008), mentioned by others, contributes to a diverse economies framework that looks beyond monetised 'market' transactions to cooperatives, gift-giving, household and community production, and volunteering. I wonder, though, if these activities are so very different from our common notions of capitalism; altruism rarely rears its ugly head in human interaction. In a current ARC project looking at how museums and individuals built their natural history collections in the nineteenth century, we find a global trade based 
upon multifarious forms of transaction - purchase, barter exchange, and donation being the most common. In each case, self-seeking motives are clear. Most interestingly, donation, or gifting, created a deferred obligation and an opportunity to build social capital.

Capitalism is complex and elusive. Too often it is used as a pejorative term to prosecute social and political 'presentist' goals or moral crusades. The evils of hegemony, inequality, exploitation are all laid at the feet of capitalism when it might be argued that capitalism is just one manifestation of the injustices that humans impose on one another. This has greater credence when we recognise that, despite recent assertions, capitalism is not simply a materialist or economic system, rather that all production and exchange is socially embedded and politically relevant. These or similar views have been around a long time Granovetter (1985) in the 1980s and, arguably, Polanyi (1944) much earlier. The modern generation of economic sociologists, people like Viviana Zelizer (2010), have fostered a wider acceptance of this perspective in mainstream scholarship, though not yet with many economists.

I, nonetheless, believe that the abstraction capitalism has value in stimulating historical and contemporary debate and presents a handy contrast and complement to the specificities of much economic thinking, as Michael intimates. Unless we can achieve a closer agreement about its meaning, however, it will remain an imprecise tool of scholarship. But doubtless it will continue to be used, or climb back through the window - like most abstractions, its elusiveness is often its appeal, it can mean different things and be used for alternative purposes by each of us.

Michael Beggs: Frances notes that 'some of the most impressive recent histories of capitalism... are products of the application of straightforward historical "tools of the trade". This is absolutely true, but the history of capitalism also invites other kinds of scholarship uncomfortable for both history and social science. In Logics of History, Sewell (2005) argues for a deep encounter: social science brings structure and abstraction, while history brings attention to change, contingency and the complex richness of social life.

Historians tend to narrate a series of events 'in some semblance of its original complexity, discussing different causal features... only as they make themselves felt in the unfolding of the story' (Sewell, 2005: 98). Narratives trace causal chains. Historians are wellaware that these chains are tangled webs: the assassination of the archduke may have triggered the Great War, but only given the fragile balance of power between the geopolitical 
blocs, rigid mobilisation plans, shuffling of the economic ranks, imperial ambitions, naval insecurities, the Ottoman implosion and so on.

Even quite abstract forces appear as background causes, but historians seem reluctant to make claims about the webs of causation themselves. That we can abstract structures from events is implicit whenever we recognise that events could have been otherwise, and yet that some possibilities were more likely than others. It is a meaningful question as to whether war would have broken out without the assassination, but it is outside history's comfort zone: we cannot access the archives of parallel universes.

These webs are what social science refers to as structure, and it is up to social science to untangle them into abstract models (not necessarily formal): reducing complexity to focus on some aspects of reality while bracketing others. 'Structure' is traditionally associated with determinism, but it does not need to be. It is now common to think of structure not as mechanical repetition, but a network of relationships in which the actions of each agent are influenced by the likely responses of others. This leaves plenty of room for choice and contingency. (Econometrics also deals in counterfactuals: parameters estimated from historical data are used to make claims about what would likely have happened to the dependent variables if the independent variables had been different.)

This way of thinking potentially has much to offer history. But social science often fails to live up to that potential, because it too often lacks history's appreciation of change and of the multitude of influences at play in any conjuncture. History is disturbing to social science's abstraction. We know from much experience that reality often upends stable structures, either because of the unexpected influence of other spheres, or because of endogenously emerging surprises. A truly historical social science must be able to understand structures as things that evolve over time, and have room for contingency in the events that transform them.

As some of you noted at the outset, much of the recent scholarship has been prompted as responses to a world undergoing profound political, economic and environmental change. In what directions - in terms of research questions or interdisciplinary links do you hope to see to this renewed interest in histories of capitalism taking? What role can and should historians play in these contemporary debates - as researchers, educators and/or public intellectuals? 
Frances Flanagan: Australia enters the 2020s, the last decade the world has to avoid catastrophic ecological collapse, with an unenviable set of encumbrances: a disproportionately polluting economy, biodiversity stocks in sharp decline, and the nearhegemonic equation of social progress with the intensity of capitalist activity on the part of the political class.

As historians, we have an important role to play in historicising, contextualising and explaining the varieties of capitalist formations that have existed in Australia's past. The task is not only to consider the 'winners' and 'losers' from a system that enshrines creative destruction (although it is that), it is also to draw attention to the alternate ways of organising society that capitalism has jostled against, fed upon and sometimes even extinguished: the civic, religious, domestic, industrial and traditional Indigenous realms. Our colleagues in political economy and critical theory do a brilliant and important job in revealing the ways in which capitalism produces 'cheaps' (of nature, money, work, care, food, energy, lives); the opportunity for the historian, I think, is to do that too but also to draw in the social movements, states, churches and traditional communities who produce and defend 'sacreds', and insist that these actors also share the frames (Patel and Morre, 2018). The historian's act of 'placing' capitalism in time and space, and in insisting on its heterogeneity and partiality as one mode of co-ordination among many is, I think, an exceedingly valuable contribution to public debate. It necessarily de-naturalises, de-centres and disenchants the capitalist concepts that currently enjoy hegemony among elite decision-makers, and opens up imaginative space for alternative ways of organising society in the future.

This year, Shoshanna Zuboff (2019) published a provocative book called The Age of Surveillance Capitalism. It is not an academic historian's book, and the notion of a new 'age' is obviously a highly contestable one, but its depiction of a world in which capitalist tech companies are able to undertake fine-grained surveillance of the internal lives of populations and workers arouses a wealth of possibility for historical reflection and exploration (Zuboff, 2019). The continuities and contrasts between surveillance capitalist and non-capitalist surveillance societies, past and present, are fascinating to consider, as is the possibility of a potential return of digitally-enabled iterations of Victorian-era 'deservedness'. The book has implicit lessons, too, for labour historians, when one considers the extent to which digital technologies are enabling the minute control of workers over great distances, with minimal interpersonal or cultural entanglement or even, in some cases, an employment relationship at all (Zuboff, 2019). It seems clear that the institutions of the Fordist era are receding even further from view. In this context, and it seems essential that we historians leave behind any 
residual assumptions that the 'real' historical actors in labour histories are necessarily and always large unions, states and employers. Spatially fragmented workplaces, global supply chains stretching across the globe and precarious workers will hopefully increasingly take centre stage in new labour histories, as well the activities of powerful, but often opaque entities such as the big 4 accounting firms, management consultants and major tech firms.

In its evocation of a data-saturated world, where the AI-enabled analysis of 'data trails' increasingly stands in for human speech, Zuboff's (2019) book also made me reflect upon the new salience that the old tools of 'lived experience' social history may have in $21^{\text {st }}$ century histories of capitalism. Such experiences and sources could, potentially, be embedded within new, very wide interdisciplinary panoramas, that locate them within both capitalist and non-capitalist orders of worth, and also within the grand, slower-moving and crucial structures of climate, biodiversity, geography and demography. This turn to a grand contextualisation of capitalism, that was both micro, meso and macro, would of course require huge teams of scholars across multiple disciplines, but we would have new digital tools to assist us. Perhaps it is time for a new Annales history for the Anthropocene?

Shannyn Palmer: I agree with Frances that the historian's task of 'placing' capitalism in both time and space, shining a light on its 'heterogeneity and partiality' is exceedingly valuable in public debate. As Frances points out, by historicising and contextualising capitalist economic formations, historical research and writing can decentre the hegemonic framing of capitalist concepts and open up a space for imagining alternative ways of organising society. I think that the contributions of historians are vital in contemporary public debates about the economic, social and environmental crises we currently face, precisely because it is historians that have the tools and methods at their disposal to show us that other kinds of worlds are possible.

I think that this dislocation of capitalist economic formations is vital, especially here in Australia where the processes of settler colonial capitalism have been (and continue to be) enacted on a continent where large swathes of its landmass had resisted those economic formations. With the notable exception of northern Queensland, part of which has been hospitable to agricultural development since the 1870 s, the north of the continent has resisted the kinds of agriculture that the British imposed upon their settler colonies. The demanding geographies of the arid centre and tropical north have also presented more limited opportunities for public and private investment and a sparser population, which according to Tim Rowse (2014: 303-304) begs the question: 'to what extent was it possible for the South 
to colonise the North - that is, to generalise to Northern Australia the model of economic development and social integration that had evolved as the basis of an imagined BritishAustralian community in the southern Agricultural zones and colonial capitals?'

This idea of two Australias - North and South - is ripe for further exploration and I think that questions that seek to historicise the spatial dimensions of capitalism in Australia represent a critical avenue for historical research and writing. History shows us that the soils and climate in the north of the continent have been inhospitable to settler colonial capitalism and that geographical isolation and the subsequent distance from markets means that the north is not well placed to engage in global capitalism. Yet the settler state continues to pursue 'mastering' the north of the continent according to settler capitalist logic, the most recent example of which is the 2015 Our North, Our Future: White Paper on Developing Northern Australia (Department of Industry, Innovation and Science). The nature of the white paper highlights the way in which resource extraction has emerged as the sole source of value in Australia's arid centre and tropical north, which raises urgent questions about entanglements between colonialism, capitalism, racism and extraction in a time of climate change; questions that historians are uniquely positioned to respond to.

My own research in Central Australia has drawn my attention to other kinds of economic formations and processes that have emerged in the gaps created by settler capitalism's restricted forms in the North of Australia. In order to more deeply understand regimes of value and economic practices that have shaped Australia and that exist outside the hegemonic framing of capitalism, especially those produced by Aboriginal and Torres Strait Islander peoples, interdisciplinary approaches are vital. I have found economic geographers such as J.K Gibson-Graeme's concept of 'Diverse Economies' (2008) and economic anthropologist Jon Altman's 'Hybrid Economies' (2001) productive in thinking through historical examples of culturally diverse economic relations that don't sit comfortably with dominant representations of capitalism. I think that the renewed scholarly interest in capitalism will be further enriched by revisiting the past to reveal examples of economic practices and processes that are often overlooked due to their being characterised as 'informal' or marginal. To do so not only makes the diversity of economic processes more visible, but also, as Frances suggests, opens up a space for reimagining how we might structure our society in the future.

Michael Beggs: History never repeats, so the lessons for the present are never simple. Still, knowledge of the past can bring some perspective. For example, seeing the waves of worry 
and exuberance about the effects of automation, the intellectual historian can point to earlier rounds of these tropes in the 1960s, 1920s and indeed 1810s — and ask whether this time really will be different (Woirol, 1996). Or, the economic historian can compare productivity data with that of previous periods and ask why recent labour productivity growth has been relatively slow if we are truly beginning an automation revolution, or how the changes to daily life brought by computing and electronic communications compare with, say, the arrival of indoor plumbing and electricity decades earlier (Gordon, 2016).

More subtly, historians have plenty to offer in contemporary debates because the historical imagination is not only about the past, but about change. 'Presentism' is a dirty word among historians, and for good reason. But there is no reason the kind of historical social science I have been advocating here cannot be applied to very recent history-with the caveat that we lack the enormous advantages of hindsight. We cannot possibly be fully aware of the emergent structural changes taking place around us; we do not even know what to look for. But looking at the present as history coming to pass can be a fruitful way to think.

I love Frances' idea of an Annales history for the Anthropocene. The importance Braudel (1972) gave the environment looks quite prescient. The Annales sense of multiple social dimensions with different, overlapping temporal rhythms is a much-needed counterweight to the crude periodisations that dominate critical social science ('Keynesianism' vs. 'neoliberalism' or 'Fordism' vs 'post-Fordism')—one-dimensional characterisations of 'regimes', reducing the many scales of social structure to a false unity, often located in policy.

The alternative would study society as made up of a number of structures, interpenetrating but with some autonomy, each changing over time both according to internal dynamics and in reaction to change elsewhere. For example, in my own work on the history of Australian macroeconomic policy, explanation took me into a number of spheres: international monetary frameworks and world commodities markets, the arbitration system, the unions and the labour market, the economics of both academics and central bankers, the banking and broader financial system, parliamentary politics, and so on (Beggs, 2015). Each of these areas evolved over time at different paces, while sudden shocks and slower tectonic drifts transmitted between them as they transformed one another's contexts.

This way of thinking about history is really a way of thinking about society: as a complex and overlapping set of structures that develop over time. This kind of historical imagination is well set up to understand the present and project possible futures. We do not have the hindsight here that historians normally enjoy, but on the other hand we have the 
advantage of direct experience of our own time, and even, potentially, some small influence over what follows - both of which future historians of this period may envy.

Simon Ville: Historians can and should contribute to contemporary debates - as researchers, educators and public intellectuals. To contribute meaningfully to the challenges facing contemporary society, we need to move away from the rhetoric of an hegemonic capitalism responsible for all of our problems. Capitalism is a highly complex, contested system of production. Most firms are small scale, most employees work in white collar service industries. Employers and employees alike are individuals concerned about contemporary challenges, particularly climate change and social prejudice. Many firms are involved in important research and innovation to address climate change, most support greater fairness and wellbeing in the workplace. 'Green' projects are mainstream in the investing community. The fear of most of us, though, is whether we are doing enough about climate change.

Rather than imagining alternative economic systems, we might best contribute to contemporary debates by demonstrating the relevance of the history of capitalism. Australia's relationship with the global economy and the important role government has played are two key insights upon which historians might draw. Australian capitalism has been heavily shaped by external economic influences including huge inflows of migration, capital, innovation, and trade. Global capitalism is forcing the pace of change in Australia today; for example, since we no longer manufacture vehicles we will be pushed into the rapid adoption of electric vehicles by the plans and commitments of foreign governments and companies.

The role of government in the Australian economy as regulator, facilitator and participant was captured by Noel Butlin's (1959) oft-used 'colonial socialism' epithet. Understanding the historical influence of governments in shaping capitalism and addressing its effects provides important lessons for contemporary debates. The basic or living wage system arising from the Harvester Judgement of 1907 is an important example of a long-term social policy that was distinctive for the shape of Australian capitalism. In more recent history, competition policy, particularly since the formation of the Australian Competition and Consumer Commission in 1995, has played a constraining role against some of the excesses of deregulated markets.

Forging interdisciplinary links is important to hearing our voices inside and beyond the academy. Along with others, I have always valued the Annales approach to history. However, I wonder if we need to extend ourselves more broadly across the spectrum of disciplines than a reimagined Annales school. The challenges and opportunities we encounter 
today often relate to science, technology and health. We should have a voice here. At Wollongong, engineers have been working for several years on the development of a lowcost eco-friendly sodium storage battery, one of a number of groups striving to overcome the major hurdle to the extension of solar power. What can historians contribute to understanding the processes of invention and innovation today: why innovation in Australia has been concentrated in particular industries or periods of time, the types of organisation that have proved effective crucibles of invention, and the relationship between public and private sectors in fostering change. Comparative history is also highly relevant here - why have some societies attracted more creativity, broadly defined, than others. Economic historian Joel Mokyr $(2002,2017)$ has made major contributions to the relationship between creativity, innovation and capitalism in a way that integrates economic, social, cultural and intellectual approaches to history. Historians have much to contribute to 'a world undergoing profound political, economic and environmental change'.

Nick Brown: One theme running through the Journal of American History (JAH) interchange on 'The History of Capitalism' (2014) was the question of whether the new engagement with the field and concept of capitalism was best seen as a tool to be applied to a range of research projects, enriching their analytical purchase, or as itself a rigorous, coherent program setting the terms in which research agendas should be defined and pursued. It is interesting, in our exchange, to note how Yves and Ben's initial invitation to reflect on economic and material perspectives has also morphed towards capitalism in particular (which seems not only to have come through the window, but sat triumphantly at the head of our table). And, on balance, we seem to be taking the first option, primarily considering the appropriate level of abstraction with which we should draw on economic perspectives to explain a range of historical issues and legacies that, in a sense, have a prior claim on our interest as historians. Whereas that American conversation often returned to race and slavery as shared concerns, our focus has instead frequently come back to inequality and environmental degradation as the issues most pressing for attention. These emphases are revealing of the purposes to which we are putting our interest in economic materialism, at the levels of analysis, advocacy and perhaps national historiographical preoccupations. What core research agendas or roles in contemporary debate might arise from these observations? As Michael has argued, 'understanding capitalism depends on dealing with economic structures that cannot simply be narrated' in social science typologies, but need (in 
a term many of us have emphasised) to be 'contextualised' in their specificities: to be, as Frances saw it, to be denaturalised, decentred and disenchanted.

That is true, but the tension in the $J A H$ (2014) discussion is still salient in getting the balance right between adding a materialist dimension to the defamiliarisation of the past, to understanding its lived experience, and/or dealing with the kind of metanarrative - and metaanalysis - that is perhaps always inherent in the deployment of capitalism as an historical tool. Yes, it is no doubt part of the attraction of capitalism that it elicits much productive, creative work in definition (or in avoiding definition). But, as Simon suggests (unless I am putting words on his page) it is still important to do the fine-grained work of understanding the specific materialities of production and consumption before we test their fit with 'hegemonic capitalism'.

In our contemporary 'space' of increasing social and environmental stresses, this balance, and need, is even more precarious. The danger of historicising capitalism can be (ironically) its normalisation around linearity and adaptation. The danger of 'crisis management' can be (equally ironically) a version of Stuart Hall's 'moral panic cycle' in which ethical imperatives cloud attention to deeper causes and implications (Feldner, Vighi and Žižek, 2014; 3). This, it seems to me, is the challenge the practice of politically engaged history now, in particularly acute terms, faces. It is a challenge that a more rigorous attention to the materialist approaches to the past and the present can assist in addressing by insisting (again) on an understanding of the structural determination of social processes and (dare I say) consciousness/conscience. And, picking up on Frances' reference to Zuboff's work on 'surveillance capitalism', part of the challenge is not simply to reject concepts of 'the market', but to actively identify those instances of 'market failure' (as in the accelerating 'disconnect between supply and demand' associated with 'surplus behavioural data') that are too easily hidden (Laidler, 2019).

In that task, of course, context is everything. Our allusions to the Annales model are significant here - accepting, as Frances and Simon (and William Sewell) argue, that an 'Annales for the Anthropocene' will need to especially attend to global systems, with the micro- of technology, science, health etc as well as the macro- of prices, population and production; and, equally, with the macro-histories of commodification as well as the microhistories of mentalités (Sewell, 2014).

Michael Beggs: Simon writes that 'we need to move away from the rhetoric of a hegemonic capitalism responsible for all our problems' and perhaps give up 'imagining alternative 
economic systems'. 'Employers and employees alike' may well be concerned about climate change and 'support greater fairness and wellbeing in the workplace'-but can the system deliver? There is a widespread feeling that however good the intentions, business and the technocratic politics of the past few decades have not been up to tackling systemic challenges, precisely because they call for systematic change. The centre has been swarmed by an atavistic right, and by the equally surprising re-emergence of a substantial left - though perhaps not yet in Australia.

'Capitalism' was defined in contrast not only with the historical societies from which it departed (e.g., the no-less-controversial ideal type, 'feudalism'), but also with socialism-a hypothetical future, or the actually-existing planned economies. The decline of 'capitalism' as a scholarly category was tied to the fall of the latter and the collapse of confidence in the former. Conversely, the revival of the 'history of capitalism' has some connection to the left's revival.

The socialist project was never simply 'anti-capitalist'. Marxists were traditionally ambivalent about capitalism. It eroded old hierarchies and radically increased productivity by organising the social division of labour and sustaining a competitive drive to endless waves of technological development. But it also entrenched new hierarchies and subordinated much of life to the accumulation of capital. The socialist hypothesis is actually that the capitalist system is not monolithic: it is possible to maintain the complex division of labour and technological creativity, with its potential for leisure and freedom from want, while pursuing egalitarianism and extending democracy.

The new wave of socialists have learned from the history of planned economies also. (Francis Spufford's (2010) Red Plenty is a brilliant dramatisation of the hopes and problems of planning.) Many recent socialist visions have room for markets (Olin Wright, 2016: 61; Sunkara, 2019), while others have highlighted the grand-scale planning on which the private bureaucracies of capitalism depend (Phillips and Rozworski, 2019). They build on decades of socialist economists' thinking about markets and pricing: from Lange and Kantorovich to Nove and Roemer.

Turning back to capitalism: one period surely ripe for historical rethinking is the post1945 long boom and its aftermath. The third quarter of the twentieth century was a 'golden age' for capitalism (eds Marglin and Schor, 1991) especially in the rich world-combining more-or-less full employment with rapid productivity gains and a growing public sector and redistributive apparatus. But it proved unsustainable through the stagflationary crisis of the 1970s. 'Neoliberalism' is the left's standard explanation, but this is too simple. It exaggerates 
the coherence of policy before and after, and reduces the system to an expression of policy. The political-economic turn of the 1970s and 1980s did as much as the fall of the Soviet bloc to take 'capitalism' off the scholarly agenda. Revisiting the puzzle of the crisis of liberal social democracy would be a promising way for scholars to engage and inform radical political movements.

\section{Reference List}

Arnason J (2001) Capitalism in Context: Sources, Trajectories and Alternatives. Thesis Eleven 66: 99125.

Altman, J C (2001) Sustainable development options on Aboriginal land: The hybrid economy in the twenty-first century.

Bauman, Z (2002) The $20^{\text {th }}$ Century: The End of the Beginning. Thesis Eleven 70: 15-25.

Beggs, M (2015) Inflation and the Making of Macroeconomic Policy, 1945-85. Basingstoke, UK: Palgrave Macmillan.

Beilharz, P (2005) Australia: The Unhappy Country, or, a Tale of Two Nations. Thesis Eleven 82: 7387.

Beilharz, P \& Cox, L (2007) Review Essay: Settler Capitalism Revisited. Thesis Eleven 88: 112-124.

Bell, D (1974) The Coming of Post-Industrial Society. London: Heinemann. 
Belnave, N \& Patmore, G (2017) The Labour Movement and Co-operatives. Labour History 112: 724.

Braudel. F (1972) The Mediterranean and the Mediterranean World in the Age of Phillip II. London: William Collins Sons \& Co.

Braudel, F (1977) Afterthoughts on Material Civilisation and Capitalism. Baltimore: Johns Hopkins University Press.

Butlin, N (1959) Colonial socialism in Australia. In Aitken HGJ (eds) The State and Economic Growth. New York: Social Science Research Council.

Chakrabority, A (2018) The post-crash world: how the 2008 crisis led to our current age of extremes. New Statesment, 15 August, viewed 17-23 August 2018, 〈https://www.newstatesman.com/2018/08/adam-tooze-crashed-decade-financial-crisis-review>

Connell, RW \& Irving TH (1980) Class Structure in Australian History: documents, narrative and argument. Melbourne: Longman Cheshire.

Delanty, G (2010) Civilizational Analysis and Critical Theory. Thesis Eleven 100: 46-52.

Department of Industry, Innovation and Science (2015) Our North, Our future: White Paper on Developing Northern Australia. Australian Government, Department of Industry, Innovation and Science, viewed 17 January 2019, <https://www.industry.gov.au/data-and-publications/our-north-ourfuture-white-paper-on-developing-northern-australia>.

Dobb, M (1947) Studies in the Development of Capitalism. New York: International Publishers.

Enstad, N (2019) The "Sonorous Summons" of the New History of Capitalism, Or, What Are We Talking about When We Talk about Economy? Modern American History 2: 83-95.

Feldner, H, Vighi, F \& Žižek, S (2014) Introduction in Feldner et al (eds) States of Crisis and PostCapitalist Scenarios. London: Ashgate.

Flanagan F (2019) Climate Change and the New Work Order. Inside Story, 28 February, viewed 13 August 2019, < https://insidestory.org.au/climate-change-and-the-new-work-order/>. 
Flew, T (2014) Six theories of neoliberalism. Thesis Eleven 122: 49-71.

Forsyth, H (2019) Reconsidering Women's Role in the Professionalisation of the Economy: Evidence from the Australian Census 1881-1947. Australian Economic History Review 59(1): 55-79.

Forsyth, H \& Loy-Wilson, S (2017) Seeking a New Materialism in Australian History. Australian Historical Studies 48 (2): 169-88.

Gibson-Graham, JK (2006) The End of Capitalism (As We Knew It): A Feminist Critique of Political Economy. Minneapolis, University of Minnesota Press.

Gibson-Graham, JK (2008) Diverse Economies: Performative Practices for “other worlds”. Progress in Human Geography 32 (5): 613-632.

Gibson-Graham, JK (2014) Rethinking the Economy with Thick Description and Weak Theory. Current Anthropology 55 (S9): 147-53.

Gordon, R J (2016) The Rise and Fall of American Growth: the US standard of living since the Civil War. Princeton: Princeton University Press.

Granovetter, M (1985) Economic Action and Social Structure: The Problem of Embeddedness. American Journal of Sociology 91 (3) (1985): 481-510.

Hartigan-O'Connor, E (2016) Gender's Value in the History of Capitalism. Journal of the Early Republic 36 (4): 613-35.

Hatton, E (2011) The Temp Economy: From Kelly Girls to Permatemps in Postwar America. Philadelphia: Temple University Press

Hilt, E (2017) Economic History, Historical Analysis, and the "New History of Capitalism". The Journal of Economic History 77 (2): 511-36

Hyman, L (2018) Temp: How American Work, American Business and the American Dream Became Temporary. New York: Penguin.

Huf, Ben and Glenda Sluga (2019) New Histories of (Australian) Capitalism. Australian Historical Studies. 
Hobsbawm, Eric (1997) On History. London: Weidenfeld and Nicolson.

'Interchange: The History of Capitalism' (2014) Journal of American History 101 (2): 503-36.

Kocka, J \& Van Der Linden, M (eds) (2016) Capitalism. The Re-emergence of a Historical Concept. London: Bloomsbury.

Kramer, P (2016) Embedding Capital: Political-Economic History, The United States and the World. The Journal of the Gilded Age and Progressive Era 15: 331-62

Kramer, P (2017) History in a Time of Crisis. Chronicle of Higher Education, 19 February, viewed 21 August 2019, <https://www.chronicle.com/article/History-in-a-Time-of-Crisis/239208>.

Laidler, J (2019) High-Tech is Watching You: Q\&A with Shoshana Zuboff. Harvard Gazette, 4 March 2, viewed 2 July 2019,< https://news.harvard.edu/gazette/story/2019/03/harvard-professorsays-surveillance-capitalism-is-undermining-democracy/>

Levy, J (2017) Capital as Process and the History of Capitalism. Business History Review 91 (3): 483510.

Liagouras, G (2005) The Political Economy of Post-Industrial Capitalism. Thesis Eleven 81 (1): 2035 .

Lipartito, K (2016) Reassembling the Economic: New Departures in Historical Materialism. The American Historical Review 121 (1): 101-139.

McLean, I (2016) Why Australia Prospered: The Shifting Sources of Economic Growth. Princeton: Princeton University Press.

McQueen, H. (1970) A New Britannia. Ringwood: Penguin Books.

Margo, RA (2018) The Integration of Economic History into Economics. Cliometrica 12 (3): 377-406

Marglin SA \& Schor JB (eds) (1991) The Golden Age of Capitalism: reinterpreting the postwar experience. Oxford: Clarendon Press. 
Mason, P (2016) PostCapitalism. London: Allen \& Lane.

Mokyr, J (2002) The Gifts of Athena: Historical Origins of the Knowledge Economy. Princeton University Press.

Mokyr, J (2017) A Culture of Growth: the Origins of the Modern Economy. Princeton University Press.

Moore, JW (2017) The Capitalocene, Part I: On the Nature and Origins of our Ecological Crisis. Journal of Peasant Studies 44 (3): 594-630.

Murphy, P (2005) Knowledge Capitalism. Thesis Eleven 81 (1): 36-62.

Olin Wright, E (2016) Socialism and Real Utopias. In: Hahnel, R \& Olin Wight, E (eds) Alternatives to Capitalism: proposals for a democratic economy. London: Verso, 61-84.

O'Sullivan, M (2018) The Intelligent Woman's Guide to Capitalism. Enterprise \& Society 19 (4): 751-802.

Palmer, B D (2017) "Mind Forg'd Manacles" and Recent Pathways to "New" Labor Histories. International Review of Social History 62: 279-303

Paternoster, H (2017) The Need for Political Economy in Class Analysis: Rediscovering Andrew Wells. Journal of Australian Political Economy 79: 102-132.

Patel R \& Moore, JW (2018) A History of the World in Seven Cheap Things: A Guide to Capitalism, Nature and the Future of the Planet. London: Verso.

Peters, MA (2012) Bio-informational capitalism. Thesis Eleven 110 (1): 98-111.

Phillips, L \& Rozworski, M (2019) The People's Republic of Walmart: how the world's biggest corporations are laying the foundations for socialism. London: Verso.

Plumpe, W, Lenger, F \& Kocka, J (2017) Capitalism as a Problem of Historiography. Journal of Modern European History 15 (4): 457-88.

Polanyi, K (1944) The Great Transformation. New York: Farrar \& Rinehart. 
Quinlan, M (2017) The Origins of Worker Mobilisation: Australia 1788-1850. New York: Routledge.

Rowse, T (2014) Indigenous Heterogeneity. Australian Historical Studies 45 (3): 297-310.

Schuessler, J (2013) In History Departments, It's Up With Capitalism. New York Times, 6 April, Viewed 21 August 2019, < https://www.nytimes.com/2013/04/07/education/in-history-departmentsits-up-with-capitalism.html>

Sewell, WH Jr. (2005) Logics of History. Chicago: University of Chicago Press.

Sewell, WH Jr. (2010) A strange career: The historical study of economic life. History and Theory 49 (4): $146-66$

Sewell, WH Jr. (2014) The Capitalist Epoch. Social Science History 38 (1-2): 1-11

Smith, K (2018) Amidst New Things: New Histories of Commodities, Capital and Consumption. The Historical Journal 61 (3): 841-861

Spufford, F (2010) Red Plenty. London: Faber and Faber.

Sunkara, B (2019) The Socialist Manifesto: the case for radical politics in an era of extreme inequality. New York: Basic Books.

Tawney RH (1930) Foreword. In: Weber, M, The Protestant Ethic and the Spirit of Capitalism. London: Unwin University Books, 1-11.

Thrift, N (2006) Re-inventing Invention: New Tendencies in Capitalist Commodification. Economy and Society 35 (2): 279-306.

Tooze, A (2018) Crashed: How a Decade of Financial Crisis Changed the World (New York: Viking, 2018)

Ville, S \& Withers G (2015) (eds) The Cambridge Economic History of Australia. Melbourne: Cambridge University Press. 
Ville, S \& Wright C (2017). Neither a Discipline nor a Colony: Renaissance and Re-Imagination in Economic History. Australian Historical Studies 48 (2): 152-68

Wallerstein, I, Collins, R, Mann, M et al (2013) Does Capitalism Have a Future? Oxford: Oxford University Press.

Wagner, P (2001) “Modernity, Capitalism and Critique”. Thesis Eleven 66 (1): 1-31.

Wagner, P (2010) Multiple Trajectories of Modernity: Why Social Theory Needs Historical Sociology. Thesis Eleven 100: 53-60.

Watson, I (1990) Fighting Over the Forests. Sydney: Allen and Unwin.

Watson, I (2016). "Wage inequality and neoliberalism: The Australian experience". Journal of Industrial Relations, 58 (1): 131-149.

Watson, I (2015) A Disappearing World: Studies in Class, Gender and Memory. Melbourne: Australian Scholarly Publishing.

Wells, A (1989) Constructing Capitalism: an economic history of eastern Australia. Sydney: Allen and Unwin.

Wheelwright EL (1983) Introduction. In: Wheelwright EL \& Buckley, K (eds) Essays in the Political Economy of Australian Capitalism. Sydney: Australian and New Zealand Book Company, 1-11.

Wheelwright, EL \& Buckley, K (eds) (1975) Essays in the Political Economy of Australian Capitalism, (5 vols). Sydney: Australia \& New Zealand Book Company.

Woirol, G (1996) The Technological Unemployment and Structural Unemployment Debates. Westport: Greenwood Press.

Wright, C (1995) The Management of Labour: a History of Australian Employers. Melbourne: Oxford University Press.

Wright, C (2015) Climate Change, Capitalism and Corporations: Processes of Creative SelfDestruction. London: Cambridge University Press. 
Zelizer, V (2010) Economic Lives: How Culture Shapes the Economy. Princeton: Princeton University Press.

Zuboff, S (2019) The Age of Surveillance Capitalism: The Fight for the Future at the New Frontier of Power. London: Profile Books. 